\title{
光開裂性ナノ粒子の開発と光線療法への展開
}

\author{
加藤 大
}

\section{Development of Photodegradable Nanoparticle for Phototherapy}

\author{
Masaru Kato \\ Graduate School of Pharmaceutical Sciences, The University of Tokyo, GCOE-CMSI Laboratory; \\ 7-3-1 Hongo Bunkyo-ku, Tokyo 113-0033, Japan.
}

(Received September 8, 2011)

\begin{abstract}
Proteins have several remarkable advantages over conventional chemical catalysts. For these reasons, proteins are widely used in many fields. We have developed a hydrogel-based protein immobilization scheme that allows proteins to maintain their activity for a long period of time. Recently, we developed a photodegradable hydrogel and used it to control the biological activities of proteins. Protein activity is restricted when the protein is encapsulated within the gel, and the activity is restored when the protein is released from the gel by UV irradiation. It is expected that the drug delivery using the photodegradable hydrogel and phototherapy is a good combination for therapy of psoriasis vulgaris.
\end{abstract}

Key words — protein; photodegradable hydrogel; phototherapy; bioassay

\section{1. はじめに}

タンパク質は大きさが数ナノメートルの物質であ り，選択性に優れ，生体親和性が高く，環境負荷が 低く，反応の効率がよいなど優れた性質を有する. そのため，酵素アッセイ，バイオセンサー，ELI$\mathrm{SA}$ 等の分析化学分野や，タンパク質製剤の医療分 野，バイオレメデーションの環境浄化など，様々な 分野で利用されている。しかし一般的に，タンパク 質には，精製物を大量入手するのが難しく，また変 性・失活し易く，そして機能を制御する汎用的な手 法がないという問題が残されていた.

大量入手が困難なタンパク質を利用するには，必 要なタンパク質の量を減らし，少量のタンパク質を 有効に活用すればよいと考えられた。そのために機 能を維持した状態でタンパク質を微小な領域に固定 化して利用することにした．タンパク質を微小な領 域のみに固定化することで必要なタンパク質の量が 減少し，また固定化によってタンパク質の繰り返し 利用が可能になり，少量のタンパク質の有効利用が

東京大学大学院薬学系研究科医工薬 GOE 支援研究室 ( 113 -0033 東京都文京区本郷 7-3-1)

e-mail: kato@ @nbi.t.u-tokyo.ac.jp

本総説は, 日本薬学会第 131 年会シンポジウム S07 で 発表したものを中心に記述したものである.
実現すると考えた。

\section{2. タンパク質固定化ゲルの開発}

タンパク質の固定化法として，われわれはゲルが 形成する網目構造を利用することにした。ゲルの網 目構造が，タンパク質より十分に小さければ，タン パク質はゲルに内包され，固定化される．またゲル 化条件を調節することで，ゲルが形成される領域の 制御が可能なため, 目的の微小領域のみにタンパク 質の固定化が可能になる．さらにゲル内を親水的環 境に保つことで，内包されたタンパク質の安定性の 向上が期待された.

タンパク質を内包するゲルには，アルコキシシラ ンの重合反応で形成されるシリカゲルを用いた。 あ らかじめ加水分解したアルコキシシラン溶液に, 緩 衝液に溶解したタンパク質を添加することでタンパ ク質内包ゲルを調製した（Fig. 1).1）重合反応によ ってシリカの網目構造が形成されるときに, 反応溶 液内に存在するタンパク質を取り囲むように網目構 造が形成されるため，タンパク質はゲルに内包さ れ，固定化される．固定化されたタンパク質とゲル の網目構造との間には，化学結合が不要なため，本 ゲルは物性の異なつた様々なタンパク質の固定化に 利用でき，これまでにアルブミン，トリプシン，キ モトリプシン，リン脂質の二重膜に内包されたチト 
(a)

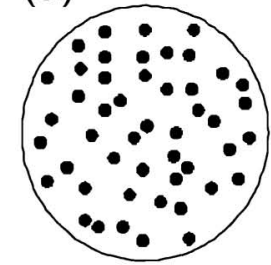

(b)

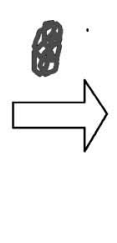

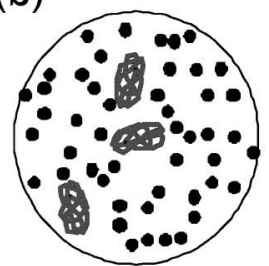

(c)

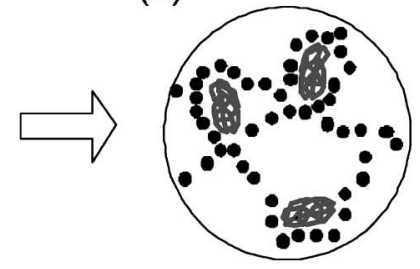

(a) Formation of sol particles during hydrolysis and condensation.

(b) Addition of biomolecules into the sol.

(c) The growing silicate network traps biomolecules.

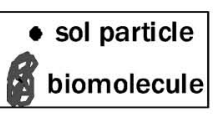

Fig. 1. Schematic Image of Protein-encapsulation in Silicate Matrix

クローム P450 など，様々なタンパク質を，機能を 維持した状態でゲル内に固定化することに成功して いる. ${ }^{2-5)}$

またタンパク質内包ゲルの形状は, 反応溶液を導 入した容器の形状によって規定される.つまり溶液 が導入できる形状であれば，様々な場所にいろいろ な形状のタンパク質内包ゲルの作製が可能である.

われわれは，これまでにキャピラリー管，多穴プ レート, マイクロチップやセンサー表面にタンパク 質内包ゲルを作製し，内包したタンパク質の機能を 利用した分析法を開発してきた.

例えば，本ゲルをキャピラリー管内に調製する と，タンパク質を固定化したカラムとして利用でき る.内径 $75 \mu \mathrm{m}$ のキャピラリー内にトリプシンを 内包したゲル $(70 \mathrm{~nL}$ 程度）を固定化し，キャピラ リー内でトリプシンによる酵素反応，生成物と未反 応物の分離及び生成物の検出を試みた。トリプシン の基質であるブラジキニンを分析した結果，1 本の キャピラリー内でブラジキニンの消化，生成物の分 離, 検出に成功した. トリプシンはカラム内に固定 化されているため, 繰り返し利用でき, さらにカラ ムの作製に必要なトリプシン量も一般的なチューブ を使用した消化反応と比較すると約 $1 / 200$ と大幅に 削減された。 また反応速度 $V_{\text {max }}$ を測定した結果, キャピラリーに固定化することで, 約 700 倍増加し た. したがって微小領域に固定化することで, 少量 のトリプシンで十分となり, さらに酵素活性の増加 がみられた. ${ }^{2)}$ 以上のことから, 精製物の大量入手 が困難なタンパク質に対してもゲルを利用して微小 領域に固定化することで, 少量のタンパク質で目的 の分析操作を実施できることを示せた. また一般的 にトリプシンは, 溶解して保管すると 1 日程度で活
性がほとんど消失するのに対し，ゲルに内包した場 合は連続して使用しても翌日までは活性を維持して いた。 つまりトリプシンは, ゲルに内包されると安 定性が向上した。これは溶液内では, トリプシンが 自由に動くことができトリプシン同士の自己消化反 応が進行するのに対し, ゲル内では動きが制限され ているため自己消化反応が起きづらいためと考えら れる. 以上の結果より, タンパク質の壊れ易いとい う欠点についても, ゲル内に内包することで克服で きる可能性が示された.

\section{3. 光開裂性ゲルによるタンパク質の機能制御}

次に, 汎用的な機能制御法がないというタンパク 質の残された欠点を克服するための検討を試みた.

これまではタンパク質をゲルに内包させ，ゲル内で 基質とタンパク質の反応を行ってきた. しかし基質 がゲル内に入り込みタンパク質と作用するには, 電 気浸透流などを利用して基質をタンパク質が存在す る場所まで届ける必要があった。 より簡単に, かつ 様々な基質との反応を制御するために，刺激によつ てゲルが崩壊し，内包していたタンパク質が放出さ れ機能させることができるゲルの開発を行った. 夕 ンパク質が，ゲルに内包されているときは機能が抑 制され，光刺激によってゲルが崩壊し，放出される と機能が発現することを期待した. 光刺激によって ゲルを崩壊させるために, ゲルの網目構造の中に光 照射によって開裂する構造を有する新しいモノマー 分子を設計, 合成した。本モノマーとアクリルアミ ドの混合液を重合することで, 網目構造が形成さ れ，その重合時にタンパク質を添加することで，夕 ンパク質を内包したゲルが形成される. そして光照 射によって 2-ニトロベンジル基が開裂すると網目 構造が壊れるため, 内包されていたタンパク質が放 


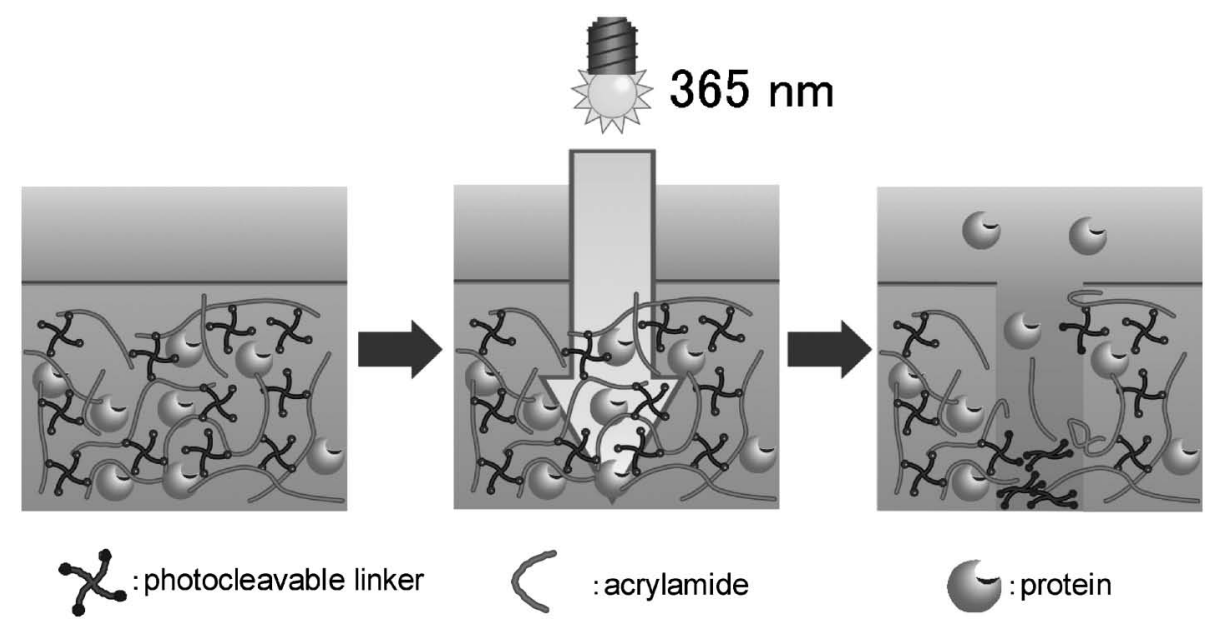

Fig. 2. Schematic Image of Photocontrol of Protein Activity Using Photodegradable Hydrogel
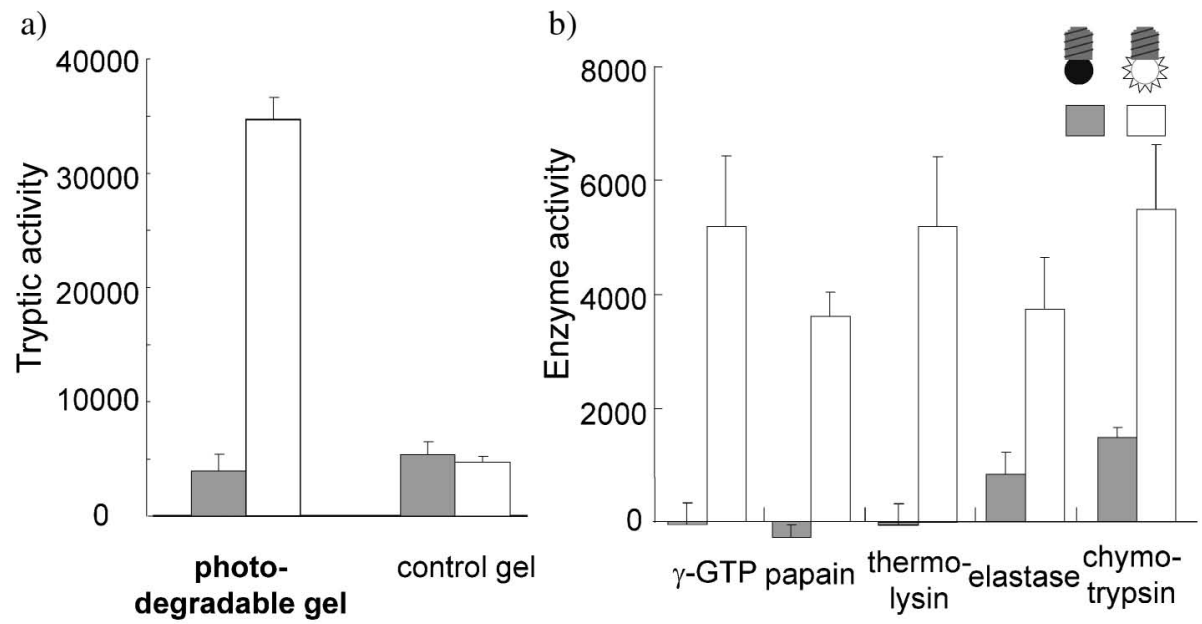

$86 \mathrm{k}$ Da $38 \mathrm{k}$ Da $37 \mathrm{k} \mathrm{Da} 25 \mathrm{k} \mathrm{Da} 25 \mathrm{k} \mathrm{Da}$

Fig. 3. a) Regulation of Enzymatic Activity Using the Photocleavable Hydrogel, b) Enzymatic Activities of Five Different Enzymes Encapsulated within Hydrogel Networks

Gray bars represent enzymatic activities before irradiation, and white bars represent those observed after irradiation.

出され，機能を発現すると期待される（Fig. 2). ${ }^{6)}$ つまり本光開裂性ゲルに内包されたタンパク質は, 光照射によって機能発現するタイミングを制御でき ると予想した。

はじめに, 光開裂基である 2-ニトロベンジル基 を有するゲルと有さないゲルを調製した。 それぞれ のゲルにトリプシンを内包させ，光照射前後（UV $=365 \mathrm{~nm}$ ）でのトリプシン活性を比較した。照射 前は，両者のゲルともほとんどトリプシン活性を示 さなかったのに対し，光照射後は光開裂基を有する ゲルのみで大幅なトリプシン活性の上昇が確認され た [Fig. 3(a)].したがってゲルの網目構造内に 2ニトロベンジル基を導入することで, 光照射により
ゲルの網目構造が崩壊し，内包していたタンパク質 が放出され，機能を発現した.

本ゲルも網目構造を利用してタンパク質を内包し ていることから，物性の異なった様々なタンパク質 を内包し, 光によって放出し, 機能を発現させるこ とができると考えられた，そこで分子量の異なる夕 ンパク質の光による機能制御を試みた。 その結果,

Fig. 3 (b) に示した 5 種類のタンパク質を始め, こ れまでに試みたすべてのタンパク質の機能制御に成 功している.これは本ゲルでも, タンパク質とゲル の網目構造との間には化学結合が不要であり, ゲル が形成している網目構造の開裂によってタンパク質 の機能制御が実現していると考えられる。これまで 
にいろいろなタンパク質の機能制御法が報告されて いるが，タンパク質の種類を限定せず，多くのタン パク質の機能制御が可能な汎用的な手法がなく，本 手法は極めて有望であると考えている.

また上記のシリカゲルを用いた検討で，タンパク 質はゲルに内包されることで安定性が向上したこと から，同様な性質が光開裂ゲルでもみられるかを確 認した。溶解したトリプシンと光開裂ゲルに内包し たトリプシンの安定性を比較したところ，ゲルに内 包することで安定性が向上した。これまでに光開裂 ゲルを用いたタンパク質の機能制御法は存在せず, また初めての光を利用した汎用的なタンパク質の機 能制御法であることから，本手法を PARCEL (Protein Activation and Release from Cage by External Light）法と名付けた．Parcel は，英語で小包の 意味し，荷物を中に入れて，外部からのダメージよ り荷物を守り，目的の場所まで配達されると，蓋を 開けて荷物を出すという，本ゲルの役割を的確に表 現していると考えている.

\section{4. おわりに}

光刺激は, 必要な場所のみに, 必要なタイミング に，必要な強度で照射できるので，優れた非侵襲な 外部刺激として利用できる．現在，治療法の 1 つの 手段として光線療法が用いられている. 光線療法 は，非侵襲な治療法として注目を浴びており，特に 乾癬のように患部が体表面である疾患に対しては,
光照射が容易なため優れた治療法として頻用されて いる。そこで今回開発したゲルに薬を内包させ，現 在の光線療法と組み合わせることで，標的部位のみ で治療薬がゲルから放出されると期待され，薬物療 法と光線療法とを同時に行うことで，治癒効果の大 幅な向上が期待できるとともに，患部のみで薬物が 徐放されるため副作用の軽減も予想される。そこで 今後は, PARCEL 法と光線療法とを組み合わせた 乾癄の治療法を目指し，検討を行う予定である.

\section{REFERENCES}

1) Kato M., Sakai-Kato K., Matsumoto N., Toyo'oka T., Anal. Chem., 74, 1915-1921 (2002).

2) Sakai-Kato K., Kato M., Toyo'oka T., Anal. Chem., 74, 2943-2949 (2002).

3) Kato M., Sakai-Kato K., Jin H.-M., Kubota K., Miyano H., Toyo'oka T., Dulay M. T., Zare R. N., Anal. Chem., 76, 1896-1902 (2004).

4) Kato M., Inuzuka K., Sakai-Kato K., Toyo'oka T., Anal. Chem., 77, 1813-1818 (2005).

5) Sakai-Kato K., Kato M., Homma H., Toyo'oka T., Utsunomiya-Tate N., Anal. Chem., 77, 7080-7083 (2005).

6) Murayama S., Kato M., Anal. Chem., 82, 2186-2191 (2010). 